\title{
Logical Fallacy Decision the Indonesian Constitutional Court Confirmed Status Quo through Presidential Threshold 2019
}

\author{
Zulfikar Ardiwardana Wanda \\ Faculty of Law, Universitas Muhammadiyah Gresik \\ Jl. Sumatra No. 101, Gresik, Indonesia \\ Email: zulfikar9040@gmail.com
}

\begin{abstract}
Indonesia is a country that embraces the democratic system that kind of its implementation is realized in organization of a general elections every five years. In welcoming the simultaneously general elections in 2019, Lawmakers validate Law No. 7 Year 2017 on The Simultaneously Executive and Legislative General Election which create a space of debating because it is colored by Presidential Threshold at least $20 \%$ of parliamentary seats for a party participant or coalition of the political parties who propose candidates of head of executive through independent channels or the coalition lines. The legitimacy of enforcement law of Presidential Threshold is further strengthened by the Constitutional Court Decision through the mechanism of judicial review and interpreting it as an opened legal policy of the legislator. Based on the foothold, the writer conducts a legal research with legal, conceptual and political reality approaches to the validity of Presidential Threshold in the 2019 simultaneous general elections. The result of this research that the implementation of Presidential Threshold is unconstitutional and no logical to apply when the executive and legislative election are held in at the same time because it will be removed itself due to a simultaneous action and create injustice to the political parties who have passed the election but cannot nominate the independent candidates.
\end{abstract}

Keywords—General Election; Presidential Threshold; Opened Legal Policy

\section{INTRODUCTION}

Constitutional Court of the Republic of Indonesia (called as The Constitutional Court) decision, which was pronounced on January $11^{\text {th }}, 2017$ sometimes ago collapses the hope to bring up the presidential and vice presidential candidates (presidential and vice presidential candidates) from each political party participating in the election. Its decision No. 53/PUU-XV/2017 that filed by the applicants re-legitimize the presidential and presidential threshold contained in Article 222 of Law No. 7 Year 2017 on the election in the grand event of presidential election and vice president 2019 as has been done in the previous year.

This article stipulates that a political party or coalition of political parties participating in the election must meet the requirements of at least $20 \%$ of the seats of The House of Representatives or $25 \%$ of the legitimate national vote in the previous legislative elections (2014) in order to be able to bag a ticket to carry the presidential and vice presidential independently. If it is tracked through a judicial review of Presidential Threshold (PT), this decision is the fifth time consistently maintaining the applicability of PT "according to The Constitutional Court" is the open legal policy of the legislator. Previously, judicial review related to the abolition of PT was terminated by The Constitutional Court in 2005, 2008, 2009 and 2013 in which all requests of the consistent petitioners were rejected despite being colored by a number of dissenting constitutional opinion judges [1].

If examining the history of judicial review application related to threshold, the abolition of PT was first filed in the case of judicial review Article 59 Paragraph (2) of Law No. 32 Year 2004 concerning The Regional Government which was decided by The Constitutional Court on May $31^{\text {th }}$, 2005. The Article 59 Paragraph (2) contains provisions that political parties or coalitions of parties can carry candidate pairs of regional heads and deputy heads of regions if eligible minimum $15 \%$ and the acquisition of at least $15 \%$ of the valid votes of The Regional Legislative Council Elections in the respective regions. In the decisions contained in the legal considerations, The Constitutional Court declared the petitioners rejected by the argument that the determination of the threshold is the policy of the legislators as long as it is not contrary to the provisions of the constitution.

Such legal considerations are then consistently poured and developed benchmarks in 4 (four) Constitutional Court decisions which were subsequently related to the threshold of Decision No. 51-52-59/PUU-VII/2009, Decision No. 3/PUU-VII/2009, Decision Number 14/PUU-XI/2013 and Decision No. 53/PUU-XV/2017 which recently appeared. When examined carefully, precisely decided legal considerations of The Constitutional Court mentioned above either legal logic, theory/concept of law and practical real politics happen today? On this occasion the writer will try to formulate a split of thoughts that poured in the form of legal reasoning as a description of the following description.

\section{RESEARCH METHOD}

This research uses normative and empirical legal research methods and uses the conceptual and case approach method. Through the research method to library about the case and concept of the presidential threshold in 
general election. Furthermore, the research was also carried out directly to the field to determine the condition of the presidential threshold in 2019. Using law books and journals relating to the case as secondary material from this study. Furthermore, in this study, an analysis based on the facts in the field and the legislation that The result of this research that the implementation of Presidential Threshold is unconstitutional and no logical to apply when the executive and legislative election are held in at the same.

\section{RESULT AND DISCUSSION}

\section{A. Three Arguments of Elimination of Elimination of Presidential Threshold in Presidential Election 2019}

In addressing the issue of PT as stated in several Constitutional Court decisions which have been mentioned above, there are at least 3 arguments or reasons that become the author's concern to declare the need to eliminate PT in the 2019 election event, namely constitutional reasoning (argumentation, conceptual-theory conceptual reasoning) and factual-political argumentation (political-factual reasoning). The first description of the optical constitutional reasoning, Article 6A Paragraph (2) of the 1945 Constitution clearly states that "A couple of candidates for President and Vice President shall be nominated by a party or a coalition of political parties participating in general elections prior to the election". If examined on the basis of interpretation in the treatise of debate when the provisions of the article were born (original intent) and grammatical interpretation (grammatical interpretation) as the method of flow of positivism interpretation [2] of the earliest and basic used, clearly mentioned in the minutes of the hearing and the text explicitly the Constitution that any political party or a combination political parties which in this case choose to coalesce with several other political parties, may submit their respective presidential and vice presidential pairs if the relevant parties are declared legally as election participants "before the election is held".

In its estuary, this method of interpretation is applied in the case of judicial review of Law no. 42 of 2008 on The Presidential Election filed by Effendi Ghazali along with Coalition of Civil Society for Simultaneous general election which later gave birth to the decision of the Court. 14/PUU$\mathrm{XI} / 2013$. In the verdict, The Constitutional Court interpreted the phrase "before the election" in the holding of legislative election and presidential elections held simultaneously even though the new entry takes effect in the next 2019 election.

Other interpretations in addition to the grammatical interpretation and original intent to explain the provisions of that article are impossible and unnecessary to be used because the textual editors and debates already recorded in the first trial treatises are very clear and do not open multiple interpretations. The Constitutional Court must restrict itself to legal interpretation without proper application parameters and must take a position to rigidly interpret the law unless that according to [4], there are situations and conditions that desperately need to be interpreted otherwise due to the existence of overlapping and multiple interpretations [3], [16]. As a first step, the first method of interpretation is to apply the two interpretive methods mentioned above in order to avoid the juridical or political deviation from what has been laid down literally or expressly in the provisions of the text of the constitution. In addition, the move also avoids The Constitutional Court so as not to easily create new norms by applying various methods of interpreting the constitution without corridors and the appropriate context so as to pseudo the legislative authority as Positive Legislator [6]. The reference [6] further confirms that the judiciary has the authority to annul a non-legally binding law. In performing this function, the judicial authority holder acts as a Negative Legislator. Read more Hans Kelsen stated:

The power to examine the laws as to their constitutionality and to invalidate unconstitutionl laws may be conferred, as a more or less exclusive function, on a special constitutional court... The Possibility of a law issued by legislative organ being annulled by another organ constitutes a remmarkable restriction of the former's power. Such a possibility means that there is, besides the positive, a negative legislator. An organ which may be composed according to a totally different principle from that of the parliament elected by the people [6].

Then the question is 1 . when the political parties are declared as participants of the election? 2. when will the election be held? And 3. when the proposal of president and vice president is done ?. Related to the first question, political parties automatically become election participants if they have passed the verification either administratively or factually by The General Election Commissions which must be fulfilled by all candidates of political parties participating in the general election according to the same Constitutional Court decision (No.53/PUU-XV/2017) which states unconstitutional if political parties that have become participants of the 2014 election do not participate in factual verification together with the new political parties previously mentioned in Article 173 paragraph (3) of The Election Law (articles that are also requested for judicial review other than Article 222). Separately, the parties included as election participants other than those clearly stated in Article 6A Paragraph (2) of the 1945 Constitution in the context of Presidential Election, are also tracked in the provisions of Article 22E Paragraph (3) and (4) namely political parties in the case of election contestation members of The House of Representatives and The Regional Legislative Council as well as individuals in the context of The Regional Representative Council members election by using systematic interpretation. The intuition is that candidates for contestants of The House of Representatives, Regional People's of Representative Assembly members and presidential election are absolute through political party path while candidate contestant of Regional Representative Council member through independent non-political party.

Turning to the second question, elections are held to elect members of The House of Representatives, Regional Representative Council, Regional People's of Representative Assembly, and President and Vice President, whose implementation time is every 5 years as stated in Article 22E paragraph (1) and (2) of the 
Constitution. Based on these provisions, it is clear that "simple legal logic" can be said that the implementation of General Election, either legislative election or presidential election is held simultaneously and united on the same day. The meanings contained in Article 6A paragraph (2) and Article 22E paragraph (1) of the Constitution based on the original intent and grammatical interpretation are elections conducted only once in the period of 5 years, not every 5 years 2 times such as the 5 th annual elections before. If it is forced to be forced to say 2 times then it is possible if there is a second round as regulated in Article 6A paragraph (4) of the Constitution.

The provision that two pairs of candidates who received the first and second most votes in the first round of Presidential elections were followed by a second round of voting mechanisms in the absence of a candidate of presidential and vice presidential candidates who failed to win a $50 \%$ vote with at least $20 \%$ of the votes in each province spread over more than half provinces in Indonesia as provided in paragraph (3) of it. However, it does not mean that the General Election is held 5 years 2 times but must be understood to be held once every year with the possibility of two rounds in accordance with the provisions set in one election event held every 5 years.

While related to the third question, when the proposal of president and vice president conducted? In order to answer that question, it must first be understood that the presidential candidate and vice president as one of the election participants included in Article 22E Paragraph (2) of The Constitution and also the absolute matters submitted by or coming from a political party or coalition of political parties before the election elections as set forth in Article $6 \mathrm{~A}$ paragraph (2), the logical consequence of the proposals of candidates and vice presidents shall be held prior to the election in which elections of participants come from political parties are elections to elect members of The House of Representatives and The People's of Representative Assembly as set forth in Article 22E paragraph (3). So it can be logically systematized that the nomination of candidates and vice presidents by political parties or coalition of political parties participating in the election must be conducted before the election of The House of Representatives and The Regional Legislative Council. The proposals must also be conducted before the Presidential Election held simultaneously with the election of The House of Representatives, The Regional Representative Council and The Regional Legislative Council as stipulated in Article 22E Paragraph (2) of the 1945 Constitution reinforced by Decision of the Constitutional Court Number 53/PUU-XI/2013 which determines the implementation of Legislative election and The presidential elections are held simultaneously in the same day.

The electoral logic of the constitutionality of elections, whether or not Legislative Election and Presidential Election are held simultaneously or not, the PT should be deleted by itself because every political party participating in the election is entitled to nominate its candidates independently or through coalition without any limitation that there should be a seat of seat ration in parliament.
Based on the logic and systematic interpretation described above, the implementation of the Legislative election which preceded the implementation of the presidential election which was conducted in the 2004, 2009 and 2014 Election is essentially irrelevant and based on the legal basis or the law that is contrary to the provisions of the constitution [4].

After the reform and amendment of the constitution, the implementation of Presidential Election and Legislative Election was separated during implementation through Law No. 12 of 2003 on Legislative election and Law No. 23 of 2003 on Presidential Election with the rule of law resulting from "wrestling and political transactions" in the parliamentary kitchen that in the election of presidential election required PT percent of percent based on the results of legislative election as a condition to submit a pair of candidates and vice presidential candidates. In Law no. 23 of 2003 on Presidential Election, the percentage of PT is determined to be at least $15 \%$ of the seats of the House of Representatives or $20 \%$ of the national legitimate votes. Then there is the political law of the General Election which was drafted by the legislators (President and House) which gave birth to Law no. 42 of 2008 concerning Presidential Election as amended by Law No. 7 Year 2017 on General Election (unification of Presidential Election and Legislative Election Act) where the percentage of its PT increasingly "rose" to $20 \%$ seats or $25 \%$ of national valid votes.

However, with the issuance of Decision of The Constitutional Court (No. 53/PUU-XV/2017) which unites Legislative election and Presidential Election on the same day based on Article 22E paragraph (1) and (2), logically it is irrelevant if it still implements PT. Strangely in the Constitutional Court's Decision raises the non-legal and legal uncertainty by stating in its decided ratio that the percentage of PT is a legal opening policy of the legislator. The verdict also states that new elections are just starting to take effect in the upcoming 2019 General Election which also opens the space for debate and polemic over legal uncertainty across the circles. Perhaps a question arises where is the unfilteredness and legal uncertainty?

The lack of logistics is impossible to instantly know the percentage of PT in the acquisition of seats in the House of Representatives or the national legitimate votes required to each political party participating in the election because to determine the percentage requires a process and time cannot be a few hours or a day finished when Legislative election and Presidential Election held on and simultaneous voting times. To "outsmart" the impossibility, the legislator through Law No. 7 of 2017 on General Election which later confirmed the legal force binding it with the Decision of The Constitutional Court Number 53/PUU-XV/2017 determines that the percentage of PT used in voting Presidential Election 2019 must refer to the results of 2014 legislative election ago. References of 2014 legislative election results to be the provisions of PT in 2019 presidential election is not relevant because it had been used in 2014 presidential election last event. If it can be said that it becomes a "stale" item to be used as a benchmark again in the next presidential election because in addition to already been used in Presidential Election of 
the previous period, also the dynamics of maps and political forces that certainly undergo changes and developments post 2014 elections.

Even more ironic, the use of PT based on the 2014 election results clearly inflicts, castrites and reduces the constitutional rights of new political parties or old who have been declared as participants in the 2019 election but do not have the percentage of PT as determined by the Election Law. The expansion of the Candidate Pair of Candidates and Candidates which is only intended to the political parties participating in the election which obtained the required PT in the previous Legislative election created an injustice in the competition of the democracy arena as well as against the spirit and spirit of the constitution. Based on the framework of Article 6A Paragraph (2) of the Constitution, both old and new political parties that have been declared passed the administrative and factual verification and have been officially declared as election participants by The General Election Commissions may submit their own presidential and vice presidential pairs without having to be torpedoed by the provisions of law "Concealment and twisting" of the constitution by political elites and rulers in formulating political policy of electoral law.

\section{B. Questioning Optics Constitutionality Opened Legal Policy Interpretation of The Constitutional Court}

Related to the opening legal policy which has been alluded to in the beginning of the above discussion, The Constitutional Court affirmed in various decisions that the PT is a legal opening policy of the legislators so that The Constitutional Court declared not authorized to interfere and test the constitutionality of determining the minimum percentage of PT which is the Positive Legislature. Based on historical records, embryo opened legal policy first appeared in the examination of the constitutionality of The Regional Government Law which gave Decision of the Constitutional Court Number 072-073/PUU-III/ 2005. The ruling states that Article 18 Paragraph (4) of the 1945 Constitution regarding the phrase "elected democratically" needs to be interpreted and interpreted openly, whether it is directly elected or representation depending on the legal choice of the legislator to decide which option, not selfregulating and limiting to one of the absolute choices. Conversely, the closed opportunity of opened legal policy can be traced in the Constitutional Court Decision Number related to the nomination of President and Vice President who must pass through political party or combination of political parties because it has been stated explicitly and explicitly as set forth in Article 6A Paragraph (2) of the 1945 Constitution.

When examined the legal considerations of several Decisions of the Constitutional Court which contains the provisions of the threshold as mentioned above, can be accumulated 4 elements, namely: 1) threshold determination is legal policy; 2) the threshold does not exceed the authority of the legislator; 3) determining threshold is not abuse; and 4) the threshold does not violate the provisions of the Constitution. Furthermore, in the Decision Ratio of the Constitutional Court Decree Number
51-52-59/PUU-VI/2008 it is explained that the norms related to the provisions of the PT have obtained the authority of the delegation from the 1945 Constitution to the legislators as meant in Article 6A paragraph (5) and Article 22E Paragraph (6) of the 1945 Constitution which in essence that the procedure and further provisions of the implementation of Presidential Election and General Election shall be regulated by law. The provision of opened legal policy related to PT more specifically stipulated by Decision of the Constitutional Court Number 14/PUU$\mathrm{XI} / 2013$ stating the provision of article of requirement of vote of political party as a condition to propose the pair of candidates/vice president is the authority of the legislator based on the provisions of the 1945 Constitution. But the interpretation and explanation of the Constitutional Court about the opened legal policy of PT is not an absolute thing. The Decision of the constitutional court is very possible to experience a shift in interpretation and direction of legal argument based on the situation and conditions and the development of the thinking of the judges of the constitution that later in the future. The reversal of logic and argumentation is highly dependent on the formulation of the applicant's legal rationality.

According to [15], the direction of legal argument reversal The Constitutional Court's verdict may experience a shift if the applicant is able to convince the judges of the constitution by doing two things. First, make a description of legal logic to ensure that the PT contains elements of violation of criteria of opened legal policy determined by the Court itself. In this case, the applicant must be able to prove or postulate that the norms of the PT petitioned are in fact inconsistent with the Constitution. If one is violated, then the norm of the PT loses the requirement that the norm be opened legal policy. Second, to deconstruct the meaning of opened legal policy which has been the basis of the Court's jurisprudence in the sense that the applicant formulates a new meaning for the opening legal policy so that the Constitutional Court can agree on the argument about the new meaning argued by the applicant [15].

From the two arguments put forward by [15] above, the author argues that the interpretation and formulation of the meaning of opened legal policy related to the formulated and always made jurisprudence by the Constitutional Court in deciding the judgment is not appropriate and inconsitative. Why? If we examine the legal logic as described above it can be explained that it is impossible that PT is used as a reference percentage in the nomination of the pair of presidential candidates and vice presidents by each political party election participants can be done because the implementation is done simultaneously in the day and time regardless of the policy of using the previous election results as a benchmark. In relation to the shift and reversal of legal arguments concerning the PT, based on the theories and practices that have occurred in the judicial world so far in the common law system, deviations from "stare decicis" doctrine may be possible if the jurisprudence used as the main source of law is no longer relevant in the case of factual reasons -contemporary and epochal development that is rationally and socially necessary to be altered and customized known as distinguishing. Whereas 
in the civil law system, constitutional legislation culminating in the constitution has a very important role and position in the source of law above custom and jurisprudence.

Today, jurisprudence in some countries in the common law system is no longer the sole main source and binding but to be equal to the law that becomes an important source of law other than jurisprudence. This can be seen in the United States where the federal government and its states each have a constitution. The same thing happened in Indonesia and Germany that embraced the civil law system in which there was a development and shift in terms of the supreme main source of law. In both countries, legislation and jurisprudence are the main sources of law and are equally important to the presence of the Constitutional Court in Indonesia and Germany, whose decisions are final and binding [11].

The second argument, based on the theory-conceptual reasoning that the People's Consultative Assembly has established by acclamation of reinforcement of the presidential system contained in one of five agreements ahead of the constitutional amendment agenda in 1999 [7]. In the frame of a presidential government system in which the filling of executive positions and members of parliament are equally elected directly by the people through elections clearly does not require the result of parliamentary elections to elect or determine the executive position as in the framework of the parliamentary system of government. Based on the logic in the system of government, the author breathed with what was stated in the dissenting opinion of two constitutional judges Saldi Isra and Suhartoyo in its legal considerations that maintaining the PT clearly undermines the logic of a presidential government system that has been adopted within the Indonesian system of government. Furthermore, if observing the system of governance in other countries such as the United States with dual party is considered a role model in presidential [18], government system and in Latin American countries that also apply the same model of government system with the combination of multiparty system as applied by Indonesia, also does not recognize PT in filling its executive position.

In the presidential system, [12] points out that the filling of the executive office is elected first, then followed by parliamentary elections or at least filling the positions held simultaneously through elections such as Philippines and others [12]. Because the election of the executive is chosen first or at least carried out simultaneously, it is not uncommon or difficult for coalitions between parties to take place. It is not uncommon in the presidential system to apply legislative/parliamentary elections first, followed by the executive/presidential election, with a coalition of political parties that reflect the pattern of parliamentary government. Based on the theory of the system of government, the imposition of PT and coalition in the presidential government system theoretically is not relevant to apply. However, the theory is disregarded with the provisions of Article 6A paragraph (2) of the 1945 Constitution in the context of a coalition that allows the nomination of candidate and vice presidential pairs proposed by a coalition of political parties other than political parties independently. In the science of law, positive law is more supreme than theory or concept even though its content is good. In order for the theory/concept to have binding legal force it needs to be arranged and institutionalized in a positive law that is confirmed by the official or authorized institution. As [7] stated that theoretical-academic truth is not necessarily or even contrary to political correctness [9].

When associated with the party's simplification mission idealized by the presidential government system as applied by the United States (Democratic Party and Republican Party) and Indonesian New Order era (Golkar, PDI and PPP), the determination of PT which is only $20 \%$ parliamentary seats or $25 \%$ of the votes legitimate national is illogical and does not guarantee the stability of the government road between executive and parliamentary relations. Why is that?. In a presidential system, the executive needs the support of a parliamentary majority in order for the stability of his administration not to be easily shaken. However, with a multiparty system implemented by Indonesia that adopts presidential system, it will face difficult situations that threaten the stability of its government and coalition becomes a difficult necessity [9]. So with the percentage of support of only $20 \%$ of parliamentary / House of Representatives seats, theoretically logic is difficult or insufficient to accumulate significant support forces, at least at least requires a minimum percentage of $50 \%$ of parliamentary seats in an effort to ensure the stability of the government.

There is no clear provision to limit the birth of political parties as a form of voicing aspiration in the organization as guaranteed in Article 28 and 28E paragraph (3) of the Constitution. This is a socio-anthropological consequence in which Indonesians live in diversity in various aspects. But that does not mean the provision prohibits to limit the number of political parties that will fight in the election. The simplification of the party may be established without having to castrate the constitutional rights of political parties who have been declared election participants by The General Election Commissions by tightening the administrative and factual verification requirements of the candidates participating in the election. Political policies are more effective to minimize and simplify the number of political parties that will fight both legislative election and presidential election. It is explicitly not a provision in the articles of the Constitution which regulates certain party system. But we can trace them implicitly from the provisions of Article 6A Paragraph (2) of The Constitution as mentioned above which define alternatively that of the candidate and vice president by political parties (independently) or the "coalition of political parties" (coalition) of the election participants. This can be interpreted and used constitutionally that the phrase "combined political parties" indicates the option of simplifying political party steps through a coalition that has been facilitated in Article 6A Paragraph (2).

The provision is to design the wheels of government in order to run relatively more effectively even though it is politically possible to form more than two coalitions. 
According to [10] that the more coalition the more potent the instability of the government because each coalition struggles for its difficult interests to determine one or the majority of votes in parliament [10]. That is why theoretically, the effectiveness of the presidential system ideally implements a party dual party system that divides between government and party parties positions proportionately to suppress the polarization of support from many political parties in parliament thus hampering the agenda and programs of government. The dual party option in the presidential system becomes a role model because it breeds a democratic political order so as to establish a checks and balances relationship between the executive and legislative branches. Such a thing is not found in a party mono system that has the potential to produce dictatorial and authoritarian governments such as Germany (before WWII) under Adolf Hitler's regime with the Nazi as his sole party.

And the third argument to be the final argument of the author, based on political-factual reasoning, legal considerations of The Constitutional Court which states that the PT is an instrument that can stabilize and strengthen the wheels of government is not a guarantee. In the era of President SBY government 1 only supported by 5 parties (Democratic Party, Golkar, United Nations, PKS and PKPI) in the popular coalition proved stable in running the government agenda at the beginning of his administration. This can happen because of changes in political maps related to the support of relations between the executive and the legislature. His embryo when Vice President Yusuf Kalla was elected and served as Chairman Golkar Party in the VII Summit in Bali which automatically made Golkar Party turn the compass needle to a populist coalition as a coalition partner of the government initially in the coalition of nationalities as opposition. In subsequent developments, the populist coalition grew fatter by deflating the coalition of nationalities in which the parties in it (PAN, PPP, PBR, $\mathrm{PKB}$ and Partai Pelopor) also migrated to the popular coalition. Thus the popular coalition becomes more dominant with the support of 10 parties in the government. While the coalition of nationalism that increasingly stubbornly post abandoned allies in congregation continue to play its role as the opposition.

Furthermore, in the era of The President Joko Widodo's government also experienced the same thing. Initially Joko Widodo was supported only by PDIP, PKB, Hanura Party and PKPI who joined in Koalisi Indonesia Hebat (KIH). But over time KIH became fatter after the PPP, PAN and Golkar who left Koalisi Merah Putih (KMP) as a coalition of equator Prabowo Subianto. Practical coalition government (KIH) which initially only filled 208 seats in the house support swelled to 386 seats in support of the government after joining the three opposition political parties. One of the factors causing such political phenomenon is because of the expertise and political party of government partners in opening the political communication room at the political parties of opposition coalition to join together to support and participate in realizing the national development political agenda. By wearing glasses with the above political dynamics, then without the percentage of PT $20 \%$ in parliament it cannot be said that the running of the government will be politically stagnant. With the start of the support of minority political parties in the house can also strengthen the wheels of government depending on the presidential expertise to embrace opposition political parties as has been practiced for this.

Furthermore, according to [3] and [16], the number of PT as stipulated in Article 222 of the election law is a "momentary" political figure that will only benefit the prospective incumbent [3], [16].. Such parties are referred to as "Status Quo" group. The Status Quo that writer refer to is the parties who still want and maintain a political situation that does not change in accordance with its interests so that the oligarchy becomes a necessity or at least potential to happen. If this is still allowed to happen then the rape of constitutional rights of political parties that have been declared as election participants but have no chance to contribute to the pairs of candidates and vice presidential candidates themselves because it stamped the rules of PT $20 \%$ in the election law which then gets constitutional legitimacy through The Constitutional Court decision. Therefore, according to the opinion of the author, The Constitutional Court decision is a manifestation of logical fallacy that affects political advantage for "Status Quo" group and also gives oligarchic nest space to the big parties who have enjoyed the power.

\section{CONCLUSION}

Based on the discussion studied and analyzed in the research, it can be taken a conclusion that Presidential Threshold enacted in Law no. 17 of 2017 on General Elections should be abolished because the logical law, normative-constitutional, factual / theoretical and factual interpretation of interpretations are unconstitutional. The implementation of Presidential Threshold in practice does not provide justice to political parties participating in the election which pass the administrative and factual verification by the KPU but can not carry the presidential candidate and vice president independently if it does not fulfill the percentage of $20 \%$ seats of DPR or national legitimate voice.

In the frame of a presidential government system in which the filling of executive positions and legislative members are equally elected directly by the people through elections clearly does not require the result of parliamentary elections to elect or determine the executive position as in the framework of the parliamentary system of government. Based on the logic in the system of governance that maintaining PT clearly undermines the logic of the presidential government system that has been adopted in the Indonesian government system and in Latin American countries with a combination of multiparty system also does not recognize the Presidential Threshold in filling its executive position.

The establishment of the Presidential Threshold as a form of a party simplification mission idealized by a presidential system of only $20 \%$ of parliamentary seats or $25 \%$ of legitimate national votes is illogical and does not guarantee 
the stability of the government road between executive and parliamentary relations because executives need parliamentary majority support for stability of government not easy to shake. However, with a multiparty system implemented by Indonesia that adopts presidential system, it will face difficult situations that threaten the stability of its government and coalition becomes a difficult necessity. So with a percentage of support of only $20 \%$ of the DPR's seats, it is not enough to accumulate significant support forces.

\section{REFERENCES}

[1] Syarief Mappiase, 2015, Logika Hukum Pertimbangan Putusan Hakim, Jakarta: Prenadamedia Group

[2] Shidarta, 2006, Karakteristik Penalaran Hukum dalam Konteks Ke-Indonesiaan, Bandung: Penerbit CV. Utomo

[3] Feri Amsari, 2013, Perubahan UUD 1945 (Perubahan Konstitusi Negara Kesatuan Republik Indonesia Melalui Putusan Mahkamah Konstitusi) Ed. Rivisi, Jakarta: PT. RajaGrafindo Persada

[4] K.C. Wheare, Konstitusi-Konstitusi Modern (Terj. Muhammad Hardani), Pustaka Eureka, Surabaya

[5] Mohammad Fajrul Falaakh, 2014, Pertumbuhan dan Model Konstitusi (serta Perubahan UUD 1945 Oleh Presiden, DPR dan Mahkamah Konstitusi (the Growth, Model and Informal Changes of An Indonesian Constitution), Yogyakarta: Gadjah Mada University Press
[6] Hans Kelsen, 1973, General Theory of Law and State, Russel \& Russel, New York

[7] Moh. Mahfud MD, 2011, Perdebatan Hukum Tata Negara Pasca Konstitusi, Jakarta: Rajawali Pers, $2^{\text {nd }}$ ed.

[8] C.F. Strong, 1975, Modern Political Constitution, An Introduction to the Comparative Study of their History and existing Form, Sidwick \& Jackson Limited, London

[9] Saldi Isra, 2013, Pergeseran Fungsi Legislasi (Menguatnya Model Legislasi Parlementer dalam Sistem Presidensial Indonesia), $3^{\text {rd }}$ ed., Jakarta: Rajawali Pers

[10] Scott Mainwaring, 1992, Presidentialism in Latin America, in Arend Lijphart (edit.), Parliamentary Versus Presidential Government, Oxford University Press

[11] T. Gayus Lumbun, 2009, Tindak Lanjut Putusan Mahkamah Konstitusi oleh DPR RI, Jurnal Legislasi, 2009, Volume 6 No. 3

[12] T.A. Legowo, 2002, Paradigma Checks and Balances dalam Hubungan Eksekutif-Legislatif, in the Conference Results Report "Melanjutkan Dialog Menuju Reformasi Konstitusi di Indonesia", International IDEA, Jakarta

[13] Act Number 17 Year 2017 about The Simultaneously Executive and Legislative General Election

[14] Decision No. 51-52-59/PUU-VII/2009, Decision No. 3/PUU-VII/2009, Decision Number 14/PUU-XI/2013 and Decision No. 53/PUU-XV/2017.

[15] Fajar Laksono Suroso, "Menguji (Lagi) Ketentuan Presidential Threshold, Mungkinkah?", http://www. hukumonline.com, accessed on February 9, 2018.

[16] Feri Amsari, Uji Materi UU Pemilu, Ahli Ungkap Alasan "Presidential Threshold" Inkonstitusional, http://www.Kompas.com, accessed on February 11, 2018. 